\title{
Review \\ Analysis of River Basin Management in Madagascar and Lessons Learned from Japan
}

\author{
Rakotoarimanana Zy Harifidy ${ }^{1, *(\mathbb{D})}$ and Ishidaira Hiroshi ${ }^{2} \mathbb{D}$ \\ 1 Integrated Graduate School of Medicine, Engineering and Agricultural Sciences, University of Yamanashi, \\ Kofu 400-8511, Japan \\ 2 Interdisciplinary Center for River Basin Environment, University of Yamanashi, Kofu 400-8511, Japan; \\ ishi@yamanashi.ac.jp \\ * Correspondence: rakzyharifidy@yahoo.fr
}

check for updates

Citation: Harifidy, R.Z.; Hiroshi, I. Analysis of River Basin Management in Madagascar and Lessons Learned from Japan. Water 2022, 14, 449. https://doi.org/10.3390/ w14030449

Academic Editors: Rafael J. Bergillos and Nikolaos Skoulikidis

Received: 29 November 2021

Accepted: 25 January 2022

Published: 2 February 2022

Publisher's Note: MDPI stays neutral with regard to jurisdictional claims in published maps and institutional affiliations.

Copyright: (C) 2022 by the authors. Licensee MDPI, Basel, Switzerland. This article is an open access article distributed under the terms and conditions of the Creative Commons Attribution (CC BY) license (https:// creativecommons.org/licenses/by/ $4.0 /)$.

\begin{abstract}
River basins in Madagascar are prone to water scarcity and conflicts of use, which are projected to worsen due to climate change. Therefore, effective integrated water resources management (IWRM) is key. This review examines the current condition of IWRM in Madagascar, evaluates its sustainability, and compares it with the one in Japan. The effects of climate change were analyzed using Aqueduct data. Madagascar has established an IWRM legal framework aligned with the Sustainable Development Goals; however, its application remains limited. For Japan, it was useful to establish IWRM for floods, water utilization, and environmental conservation. This study analyzes the future projections of water availability and demand for the 12 major river basins of Madagascar. Climate change will reduce water availability; the West and the East will experience water stress; the demand will be higher in the highlands, with less water available in the south. The proposed framework and Japan's experience in river basin management can contribute to solving those problems. The findings of this study serve to enhance the knowledge on IWRM and the impact of climate change in Madagascar; they also suggest actions to be taken by the Malagasy government.
\end{abstract}

Keywords: climate change; IWRM; Japan; Madagascar; sustainable development; river basin

\section{Introduction}

Water is the most important element for the preservation of life. Water resources underlie the production of agricultural and industrial goods and services; their careful development and management are essential to generating wealth, mitigating risks, and alleviating poverty. Water, energy, and food resources are essential for human sustainable development [1]. Global water demand will increase substantially over the next two decades in the industrial, domestic, and agricultural sectors [2]. Previous studies have demonstrated that water is becoming limited, and more careful consumption is needed. This is partially caused by increasing population coupled with changes in the consumption pattern and climate change. Recently, considerable attention has been focused on the implementation of integrated water resources management (IWRM) in global river basins, including basins in Africa. Addressing the development challenge is an increasingly important issue in African countries. By 2050, the African population growth is projected to increase by $108 \%$ of the current value [3], while industrial and domestic water demand will increase by $300 \%$ and $800 \%$, respectively [4].

Madagascar is an island country located in southeastern Africa. The country is sufficiently endowed with water resources both in terms of surface water and groundwater, but water resources are distributed irregularly in terms of seasons and geographical location. Previous studies have demonstrated that the pressures on water resources in Madagascar vary between regions [5,6]. In addition to the lack of infrastructure, various pressures on such resources threaten their existence. Water resources must cope with natural pollution because of soil erosion due to deforestation, pollution due to wastewater discharge from 
human activities, and practices such as agricultural fires (Tavy). IWRM was incorporated into Madagascar's Water Code in 1998 [7]. A policy is needed to ensure adequacy between the quantities used and the need for water resources to enable socioeconomic development within the country. Madagascar does not currently experience tensions or wars related to water resources. However, the island is exposed to various weather and climate phenomena because of its diverse landscape [8] and climate change. In 2018, the country ranked fourth among the 10 countries most vulnerable to extreme weather events [9]. Climate change has impacted virtually every river basin in Madagascar, often degrading the quality and availability of water and water-related $[10,11]$. In this paper, we explored the possibility of managing the major river basins to achieve sustainable development. For that purpose, we evaluated the existing IWRM policy, legal and strategic frameworks in Madagascar. The integrated river basin management (IRBM) in Madagascar was compared with Japan to assess the progress of both countries in the implementation of IWRM/IRBM and possible strategies for Madagascar to reach the Sustainable Development Goals (SDG) target 6.5. Japan is one of the largest and most developed economies in the world, whereas Madagascar is one of the poorest. There are important differences between Japan and Madagascar, such as the level of economic development, population density, climate, geography, culture, etc. Not all Japan's experience of river basin management can be applied to Madagascar, but some lessons can be drawn and adapted in Madagascar's context. We also used Aqueduct data to analyze the projected effects of climate change on the 12 major river basins to provide information regarding future water availability and water demand. Further, we proposed a solution to manage the basins based on the results of the precedent analysis.

\section{Materials and Methods}

\subsection{Study Area}

Madagascar is the fourth largest island on Earth. It is situated $300 \mathrm{~km}$ east of the African coast and has an area of $587,295 \mathrm{~km}^{2}$. The island has six large basins, divided into 32 macrobasins and 533 subbasins, all of which are distributed across 22 regions [7]. The island can be divided into four climatic ecoregions with four forest types: moist in the East, dry in the West, spiny in the South, and mangrove forests on the west coast [8]. Forest types are defined based on their inclusion in one of these four ecoregions. Madagascar's geographical position coupled with the island's irregular physical relief makes its climate extremely varied, which could be more accurately described as several climates differing by region. On the east coast, the climate is hot and humid, with the annual rainfall of 1100-3700 mm per year and the average temperature between 23 and $26^{\circ} \mathrm{C}$. The North and northwest regions have a tropical climate, with monsoon conditions driving rainfall in the summer. On the contrary, the southwest part is semiarid, with the annual rainfall of 500-700 mm per year. On the west coast, the climate is tropical, with a hot and dry summer. The annual average temperature varies between 24 and $27^{\circ} \mathrm{C}$. An interannual variation in temperature and precipitation is observed in the central highlands, with the annual rainfall of 900-1500 mm per year and the annual temperature range from 16 to $22{ }^{\circ} \mathrm{C}[12,13]$. Previous studies pointed out that the annual rainfall decreases from 1500 to $400 \mathrm{~mm}$ per year from north to south across the west coast while the temperatures increased by $0.2{ }^{\circ} \mathrm{C}$ over northern Madagascar and by $0.1{ }^{\circ} \mathrm{C}$ over southern Madagascar [10,12].

This study focuses on the 12 major river basins that cover areas larger than $10,000 \mathrm{~km}^{2}$ : Mangoky, Betsiboka, Tsiribihina, Mananara, Mangoro, Maningory, Mahajamba, Onilahy, Manambolo, Mahavavy, Sofia, and Mandrare (Figure 1). 
River basins: ecoregions and forest types

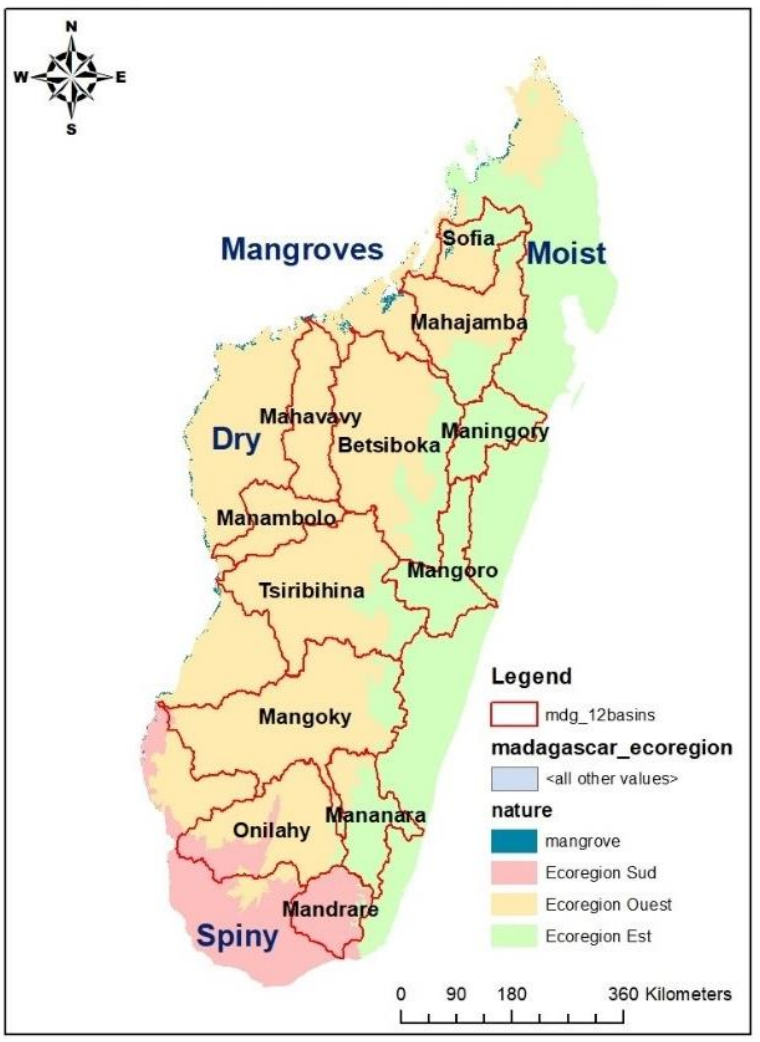

Figure 1. Delineation of catchment boundaries and ecoregions.

\subsection{Methods}

Initially, we compared the river basin management in Madagascar and Japan by evaluating the existing framework documents in terms of the effects of climate change, and then estimated the impacts of climate change on the major river basins. The island country of Japan was chosen for comparison because of two reasons. The first is similarities between Japan and Madagascar. Both countries are islands with a diverse natural environment, prone to natural disasters, suffer from the impact of climate change, but have abundant water resources in contrast to many other island countries [14,15]. Japan and Madagascar rank first and fourth, respectively, among the ten countries most vulnerable to extreme weather events in 2018 [9]. The second reason is Japan's well-known experience in water management, as well as mitigation of climate change and water-related disasters. Japan is among the countries with higher levels of IRBM implementation. This view is supported by the findings in a comparative study on river basin management in Japan and other island countries [16,17]. Indeed, the traditional water wisdom of Japan enabled the achievement of its Millennium Development Goals in 2015; currently, Japan is a global leader in water technology developed by private companies [18]. In this paper, we focused on water availability and demand issues on a large river basin scale. The analysis of these issues is an essential component for water resources assessment, which is, therefore, a significant component of the evidence and analysis required for IWRM [19]. Unlike most other countries on the African continent, no river basin management plan has been completed by Madagascar. Therefore, the next step of the research was to investigate the future changes in water stress, water supply, and water demand for the major river basins. The data were obtained from Aqueduct projections using Coupled Model Intercomparison Project Phase 5 General Circulation Models provided by the World Resources Institute [20]. The Aqueduct Project is a data platform run by the World Resources Institute, an environmental research organization (Washington, DC, USA). It provides a global water risk atlas to help companies, governments, and civil society understand and respond to water risks—such 
as water stress, variability from season to season, pollution, and water access. It intends to measure, map, and understand water risks around the globe. The Aqueduct Project is widely used by researchers across the globe because it uses open-source, peer-reviewed data to map water risks and collaborate with companies, governments, and research partners through the Aqueduct Alliance [21]. Projections of climate variables were driven primarily by the CMIP5 Project, and socioeconomic variables were based on the Shared Socioeconomic Pathways database from the International Institute for Applied Systems Analysis. The project computed water supply from the runoff values extracted from an ensemble of CMIP5 data. Herein, the total blue water or renewable surface water is used as an indicator of water supply. The projected change in the total blue water (the renewable surface water) is equal to the 21-year mean around the target year divided by the baseline period of 1950-2010. The data used by the World Resources Institute (WRI) to calculate the baseline include over 50 years of data across several indicators reported by country (FAO) to 2010. Water demand is measured as the sum of water withdrawals. The projected change in water withdrawal is equal to the total withdrawals in the target year divided by the baseline year of 2010 .

Water withdrawals were modeled from the projected size, wealth, and other characteristics of the countries, for each of the three sectors as defined by the Food and Agriculture Organization of the United Nations (FAO): agricultural, industrial, and domestic. Water stress is an indicator of competition for water resources; it is informally defined as a societal demand for water, divided by available water. Water stress was computed as the ratio of water withdrawals to the available blue water on the average annual basis. We produced maps showing the projected changes in the water stress, water supply, and water demand from the baseline (1950-2010) to the future using geographic information systems and Aqueduct future-value data for the year 2040 under the Shared Socioeconomic Pathway 2 and Representative Concentration Pathway 8.5 scenarios. We also compared the future water stress scores of Madagascar and Japan using Aqueduct country and province ranking data $(2020,2030$, and 2040). Higher scores on the scale from 0 to 5 correspond to greater competition among water users relative to the available surface water resources. All data are available at https: / / www.wri.org/aqueduct (accessed on 25 May 2020). Finally, an alternative solution for effective IWRM implementation and sustainable river basin management was considered based on the above comparisons and projections.

\section{Results and Discussion}

\subsection{Importance of IWRM toward the SDGs}

Madagascar is among the 193 countries that signed the 2030 UN Agenda [22]. Madagascar agreed to the water, energy, and food nexus concept in early 2018 within the framework of the Southern African Development Community. This concept was intended to be integrated into the discussions of IWRM. The island is one of the countries that did not reach the Millennium Development Goals by the end of 2015 [23]. The reduction of poverty by half compared with 1990, Millennium Development Goals targets, and other targets have not been achieved. Thus, Madagascar continues to be confronted by the unfinished agenda of the Millennium Development Goals. Madagascar is at the very beginning of the process of implementing the 2030 Agenda. A great effort is required to address the current and future challenges, such as eradication of extreme poverty and reduction of inequalities; protection of the environment; and access to water, sanitation, and hygiene services [24].

Japan is also committed to extensive domestic and international efforts to achieve SDGs. Japan has led the promotion of SDGs in the national and international community, building upon its strengths in traditional wisdom, cutting-edge technologies, and information. Japan promotes the SDGs on the basis of three aspects: promotion of the society, vitalization of local areas to make communities more resilient, and empowerment of next generations and women [25].

Both countries have attempted to promote the SDGs and align them with the national policies and strategies. The Japanese government sets the SDGs as the focal point of the 
national strategies: SDGs Promotion Guiding Principles and SDGs Action Plan 2018. To have Madagascar classified as an emerging country, the current government developed a new strategic document called Plan Emergence Madagascar (PEM) (2019-2023) as a component of the General Government Policy (Programme Générale de l'Etat) to ensure tangible progress toward the SDGs. The IWRM and water, energy, and food nexus approaches are used to ensure sustainable water management. Each approach has particular advantages in terms of SDG implementation. However, SDG 6.5 requires nations to "implement IWRM at all levels, including through transboundary cooperation" (https://sdgs.un.org/goals, accessed on 10 February 2020). IWRM must give priority to the creation of infrastructure, construction of local capacity, and development of an information base to provide the foundation for basin-level planning in fragile economies, such as Madagascar [26].

\subsection{Water Resources Management}

In Madagascar, only $54 \%$ of the population uses an elementary water service, $11 \%$ use basic sanitation, and more than $51 \%$ practice open defecation [27]. The management of water resources was placed under the supervision of the Ministry of Water, Sanitation, and Hygiene created in July 2008 by Decree No. 2008-829. The Ministry is responsible for the design, management, coordination, harmonization, and implementation of the National Development Plan and the General Government Policy in the sector. Under the provisions of Law No. 98-029 of 20 January 1999, bearing the Water Code, the Malagasy government created the National Authority for Water and Sanitation (ANDEA), which is an independent, non-user organization that promotes the participatory process to implement the Integrated Resource Management Process in Waters [28]. Policy, legal, and strategic frameworks of Madagascar's water, sanitation, and hygiene sector are in place and are generally well-structured. In a clear alignment with the SDGs, those documents outline the key commitments for increasing access to safe water and sanitation facilities; they also outline commitments for developing IWRM, emphasizing public-private partnerships, and growing the water, sanitation, and hygiene sector. The government has also committed to international frameworks, such as the Sanitation and Water for All initiative, the eThekwini Declaration, the Ngor Declaration on Sanitation and Hygiene, and the Rio Declarations [29]. Framework documents exist and databases are available, but applications at the field level for the project implementation remain limited or almost non-existent; thus, they require an examination. Many projects have begun to experiment with specific tools at the local scale (e.g., resource inventory) or at the regional or national (master plan) scales, but such projects are not widely disseminated. At the community level, implementation of the IWRM concept is considered ineffective [30]. The river basin management is based on the concept of decentralization. There are four levels of water resources administration depending on the territory: national (ANDEA), provincial (basin agency), regional (basin committee), and local (water point committee). Each structure has its role and responsibilities stipulated by the Water Code (Law No. 98-029 of 20 January 1999 and its 13 application decrees; https: / /jwf-legal2.fr.gd/Lois-183.htm, accessed on 5 March 2020).

In contrast, access to drinking water and sanitation is universal in Japan. An improved water source is available to $98 \%$ of the population, and $99 \%$ of the population use improved facilities [27]. The ministries involved in water-related matters are the Ministry of Health, Labor, and Welfare; the Ministry of Agriculture, Forestry, and Fisheries; the Ministry of Economy, Trade, and Industry; the Ministry of Land, Infrastructure, Transport, and Tourism (MLIT); and the Ministry of Environment. Domestic water supply falls under the supervision of the Ministry of Health, Labor, and Welfare; the Ministry of Environment is responsible for water quality and environmental conservation. Generally, water policies in Japan remain fragmented, except for the coordination between the central government and local governments during droughts and water shortages [17]. With its diverse natural environment, Japan has developed region-specific IWRM tailored to regional climatic and social conditions. Japan's IWRM promotes sustainable water use and effective water cycle governance through appropriate policy and frameworks involving relevant sectors and 
stakeholders. IWRM is promoted from such perspectives as groundwater and surface water, water quantity, and water quality (both upstream and downstream); it also promotes water efficiency and environmental conservation. In Japan, Water Plan 21 is formulated with three basic objectives: establishment of sustainable water use systems; conservation; and improvement of the water environment and fostering of a water-related culture. Water Plan 21 identifies long-term water supply and demand prospects, as well as means of improving water use stability, through water efficiency measures and effective use of the existing infrastructure [18]. River administration is based on classification of rivers into classes A and B, which contain, respectively, 109 and 2691 river systems [31]. Rivers are managed depending on the importance of their roles for the country. Class A river systems are considered important for the national economy and people's lives; they are administered by the MLIT. Class B River systems are administered by prefectural governments. Each section's responsibility is stipulated by the River Law (Law No. 69 of 4 June 1997) [32].

Table 1 lists IWRM framework documents, institutional supports, and some examples of lessons learned from the river basin management in Madagascar and Japan.

Table 1. Difference between IWRM framework documents in Madagascar and Japan.

\begin{tabular}{|c|c|c|c|}
\hline Country & Madagascar & Japan & Findings \\
\hline $\begin{array}{l}\text { IWRM framework } \\
\text { documents }\end{array}$ & $\begin{array}{l}\text { National Development Plan (Plan National } \\
\text { de Développement/PND): } \\
\text { Axis 4: Adequate human capital for the } \\
\text { development process } \\
\text { Axis 5: Development of natural capital and } \\
\text { strengthening of resilience to disaster risks } \\
\text { Sectoral Program for WASH (Programme } \\
\text { Sectoriel pour l'Eau, l'Assainissement et } \\
\text { l'Hygiène/PSEAH) } \\
\text { Sectoral strategy 2013-2018 } \\
\text { Guidelines 2019 } \\
\text { Water Code (Law No. 98-029 of } 20 \text { January } \\
\text { 1999) and its 13 application decrees: } \\
\text { Article 1: Water is part of the common } \\
\text { heritage of the Nation } \\
\text { Article 28: Priority for drinking water in } \\
\text { case of limitation } \\
\text { Article 38: All water delivered for human } \\
\text { consumption must be potable } \\
\text { Articles 29, 31, 32, 33, and 35: Development } \\
\text { of water resources "irrigation water, } \\
\text { industrial water and hydroelectric water" } \\
\text { Article 54: Investment and operating costs, } \\
\text { users' ability to pay } \\
\text { Article 69: Conservation, mobilization, and } \\
\text { protection of water resources } \\
\text { Article 73: National Water Resources Fund } \\
\text { (FNRE) } \\
\text { Articles 75 and 76: Creation of the National } \\
\text { Water and Sanitation Authority (ANDEA) } \\
\text { Decree 2003-191: Creation of basin agencies } \\
\text { Decree 2003-193/Article 10: Supply of the } \\
\text { universal drinking water service } \\
\text { Decree 2003-793/943: Authorization of } \\
\text { withdrawal and dumping } \\
\text { Decree MECIE: Alignment of investments } \\
\text { with the environment } \\
\text { Masterplans: define the division of the six } \\
\text { large basins into 32 macrobasins and } \\
\text { 533 subbasins (Decree 2003-191, chap. II) }\end{array}$ & $\begin{array}{l}\text { National Policy } \\
\text { River Law (Law No.69 of } 4 \text { June 1997) } \\
\text { Article 2: River water is public property } \\
\text { and cannot be made the subject of a } \\
\text { private right } \\
\text { Article 23: provides the permission of river } \\
\text { water users } \\
\text { Article 32: provides charging for the use of } \\
\text { river water } \\
\text { Article 34: provides the transfer of } \\
\text { water rights } \\
\text { Article 35: provides consultation with the } \\
\text { concerned administrative organization } \\
\text { Article 36: provides consultation with the } \\
\text { Prefectures and Municipalities } \\
\text { Comprehensive National Water Resources } \\
\text { Plan (1987): Water Plan 21 } \\
\text { Specified Multipurpose Dams Law } \\
\text { Water Resources Development, Public } \\
\text { Corporation Law } \\
\text { Law for Special Measures for Reservoir } \\
\text { Areas (1973) } \\
\text { Water Quality Conservation Law } \\
\text { Law for Ground Water } \\
\text { Industrial Water Law (1956) } \\
\text { Factory Effluent Control Law (1958) } \\
\text { Waterworks Law } \\
\text { Law on Execution of the Preservation } \\
\text { Project for Water Supply } \\
\text { National Land Sustainable Plan Law (2005) } \\
\text { Law for the Focused Planning of Social } \\
\text { Infrastructure Improvement (2003) } \\
\text { Forest Law } \\
\text { Sewerage Law (1970) } \\
\text { Water Pollution Control Law (1970) } \\
\text { Basic Law for Environmental Pollution } \\
\text { (1967/1970/1993) }\end{array}$ & $\begin{array}{l}\text { The Water Code and the } \\
\text { River Law set out the } \\
\text { value of water } \\
\text { (public property). } \\
\text { Both legal frameworks } \\
\text { are devoted to managing } \\
\text { and conserving the } \\
\text { water resources } \\
\text { (quantitatively and } \\
\text { qualitatively) and } \\
\text { protecting the } \\
\text { water environment. } \\
\text { Japanese framework } \\
\text { documents are revised } \\
\text { and updated regularly, } \\
\text { contrary to Madagascar. } \\
\text { Public participation in } \\
\text { the planning is required } \\
\text { by law in Japan, not } \\
\text { in Madagascar. } \\
\text { Japan's river } \\
\text { management system } \\
\text { integrates flood } \\
\text { management, water } \\
\text { utilization, and } \\
\text { environmental } \\
\text { conservation. } \\
\text { Japan has established } \\
\text { many laws aimed at } \\
\text { increasing the resilience } \\
\text { of water systems to } \\
\text { global change pressures } \\
\text { (Dams, Groundwater, } \\
\text { Waterworks; Sewerage, } \\
\text { Water Pollution } \\
\text { Control, etc.). }\end{array}$ \\
\hline
\end{tabular}


Table 1. Cont.

\begin{tabular}{|c|c|c|c|}
\hline Country & Madagascar & Japan & Findings \\
\hline $\begin{array}{l}\text { Institutional/legislative } \\
\text { supports }\end{array}$ & $\begin{array}{l}\text { National Water and Sanitation Authority } \\
\text { (ANDEA): operates the IWRM mechanisms } \\
\text { Local governments: region, district, } \\
\text { and municipality } \\
\text { Decentralized technical service (Service } \\
\text { Techniques Déconcentrés/STD) }\end{array}$ & $\begin{array}{l}\text { Water Resources Department, Land and } \\
\text { Water Bureau (MLIT) } \\
\text { Japan Water Agency (JWA): promotes } \\
\text { water resources development } \\
\text { Coordination Committee for the Promotion } \\
\text { of a Sound Water Cycle } \\
\text { Local governments: city, prefecture, } \\
\text { municipality }\end{array}$ & $\begin{array}{l}\text { The Decrees of the Water } \\
\text { Code are not } \\
\text { implemented correctly } \\
\geq \text { ANDEA is } \\
\text { nonfunctional. } \\
\text { Japan integrates five } \\
\text { ministries related to } \\
\text { water to ensure better } \\
\text { coordination of the } \\
\text { water resources } \\
\text { (intersectorality). }\end{array}$ \\
\hline $\begin{array}{l}\text { Lesson learned from } \\
\text { river basin management }\end{array}$ & $\begin{array}{l}\text { Case of the PADAP project: } \\
\text {-Application of the landscape approach } \\
\text { based on the problems of developing } \\
\text { sustainable agriculture through the } \\
\text { combination of agricultural production and } \\
\text { advanced technology. } \\
\text {-Pool the interests of each sector in the } \\
\text { implementation of activities. } \\
\text {-Development of a Landscape Management } \\
\text { Development Plan (PAGDP) } \\
\text { Case of the GIRE SAVA, GIRE Lac } \\
\text { Itasy project: } \\
\text {-Application of the bottom-up approach: } \\
\text { includes all the stakeholders and users to } \\
\text { identify the priorities in terms of need and } \\
\text { management as well as the strategies to } \\
\text { be adopted. } \\
\text {-Establishment of the basin communities at } \\
\text { the municipal level. } \\
\text {-Establishment of the Lake Itasy } \\
\text { management committee (COGELI) in } \\
\text { February } 2019 \text {. } \\
\text { Case of the KOLORANO project: } \\
\text {-Linkage of all the stakeholders in the } \\
\text { watersheds throughout the process to } \\
\text { avoid recurrent conflicts of usage between } \\
\text { drinking water and agriculture due to } \\
\text { unsuitable and non-concerted practices. } \\
\text {-Development of the watershed } \\
\text { management plan, then validated by } \\
\text { municipal decrees (local level). }\end{array}$ & $\begin{array}{l}\text { Case of the Yodo River, the Tone River, the } \\
\text { Yoshino River: } \\
\text {-Implementation of the basin governance } \\
\text { approach: governance, utilization, and } \\
\text { conservation of the diverse basin resources } \\
\text { achieved through the cooperation of / } \\
\text { partnership between government } \\
\text { departments and stakeholders. } \\
\text {-Creation of the River Basin Committee and } \\
\text { public involvement. } \\
\text {-Information sharing and stakeholder } \\
\text { participation are essential principles and } \\
\text { apply to every successful case of IWRM. } \\
\text { Stakeholders shared data and worked } \\
\text { together for unity. } \\
\text { Case of the Tama River: } \\
\text {-Roundtable conference of the stakeholders, } \\
\text { the river authority, the governors, and } \\
\text { the mayor. } \\
\text {-Active participation of the residents, the } \\
\text { municipalities, the industry, academic } \\
\text { experts, and the administrators from the } \\
\text { initial planning stage. } \\
\text { Case of Lake Biwa: } \\
\text {-Legislative framework for conflict } \\
\text { resolution between the upstream area, the } \\
\text { Lake Biwa basin, and the downstream area: } \\
\text { enactment of the Clean Lake Law in } 1984 \text {. } \\
\text {-Formulation of a comprehensive } \\
\text { conservation plan with } \\
\text { participation of all the stakeholders in } \\
\text { the basin. }\end{array}$ & $\begin{array}{l}\text { Upstream-downstream } \\
\text { coordination. } \\
\text { Public and stakeholder } \\
\text { participation in } \\
\text { the planning. } \\
\text { Adequate dissemination } \\
\text { of information and } \\
\text { communication at all } \\
\text { levels. } \\
\text { Capacity building of } \\
\text { local communities. } \\
\text { Establishment of IRBM } \\
\text { plans at the local level. }\end{array}$ \\
\hline
\end{tabular}

The table shows that both countries have laws and regulations to support IWRM and IRBM. The institutional support for IWRM implementation in Japan (MLIT) is operational, in contrast to Madagascar (ANDEA). In Madagascar, ANDEA leads decisions and actions coordinated at three established basin agencies and the 22 regional basin committees. However, the framework documents are not applied effectively; this has led to unsuccessful implementation of basin Agencies and basin committees, as well as non-establishment of the National Fund for Water Resources. Consequently, there is confusion concerning the roles and responsibilities assigned to the regional and local basin committees. In contrast, Japan's MLIT has 10 regional offices, each of which controls approximately 12 local river offices. Each organization is independent in its fields and activities and has an autonomous budget. Notably, the concepts of IWRM and IRBM require major participatory roles for all the stakeholders involved. Some reports have indicated that difficulties in the implementation of IWRM in Madagascar are caused by customs, land ownership problems, and the lack of consultation between the local population and the authorities [33]. In contrast, Japan's law requires public participation in the planning process, which makes river basin management very specific. Stakeholders work together on decentralized sites at the level of catchment areas or on the national level. The Japanese national IWRM plan, referred to as Water Plan 21, is formulated for the involvement of more than one 
local government. The establishment of the Coordination Committee for the Promotion of a Sound Water Cycle, which involves the five water-related ministries, promotes better integration and coordination of water resources. Nevertheless, a previous study noted the incompatibility of river basin organizations with the current administrative systems, which has led to conflicts between the ministries involved in water management [17]. The example projects presented in Table 1 demonstrated that IRBM represents a key factor for accelerating local development and managing water resources and their environments.

Madagascar can learn three important strategies from Japan: effective implementation of the existing IWRM frameworks; intersectoral cooperation at the river basin level and decentralization of decision-making; and sustainable management of the available water resources by minimizing adverse environmental and social impacts.

\subsection{Impact of Climate Change in Madagascar}

Madagascar established the National Climate Change Coordination Office, which reports to the Ministry of the Environment, Ecology, and Forests, in 2010 [34]. According to Decree No. 2015-092 of 5 March 2015, this Ministry is responsible for the implementation and coordination of actions, as well as the mainstreaming of climate change issues in various social and economic sectors. The impacts of climate change have been severe during the past two decades: extended drought periods, increased rainfall variability, cyclones' intensification, and floods associated with cyclonic disturbances [35]. In addition, temperatures continue to increase in nearly all the regions, and the precipitation decreases by $3 \%$ per year in some regions [36]. Furthermore, the flooding has considerably increased over the past few years in coastal cities, which has resulted in crop failures. Indeed, the maximum temperature is rising faster in the rainy season than in the dry season, except in the humid tropical climate region and at high altitudes in the center of the country. Madagascar is one of the least-developed countries with insignificant greenhouse gas emissions [35]. Primary sectors, particularly agriculture and fisheries, are prominent in the national economy. However, the country has severe problems with soil erosion and deforestation, which reduce soil fertility and productivity, thus increasing the vulnerability of agriculture and fishing-based livelihoods. Therefore, decreased agricultural yields and poor fishery performance may lead to increased food insecurity, which aggravates poverty. Moreover, the electrification level is extremely low, such that only approximately $20 \%$ of the households have access to electricity. This explains the nation's dependence on wood as fuel, which is expected to persist in the short term. Climate change will affect forests because increased temperatures and lower rainfall will lead to increased tree die-off, forest fires, fuel buildup, and insect abundance [37]. By 2050, the temperature is expected to increase by $1.1-2.6^{\circ} \mathrm{C}$ across Madagascar [38]. A study conducted by the WHO and the UNFCC [39] showed that the mean annual temperature is projected to rise by approximately $4.1^{\circ} \mathrm{C}$ from 1990 to 2100 under the high emissions scenario Representative Concentration Pathway 8.5. If global emissions decrease rapidly, the temperature rise will be limited to approximately $1.1^{\circ} \mathrm{C}$. In addition, the risks of vector-borne diseases (e.g., malaria and dengue) are expected to increase toward 2070 [40]. The increasing rate of deforestation in Madagascar is most likely associated with demographic growth and poor environmental law enforcement. If nothing is done to rapidly curb deforestation, Madagascar risks losing almost all of its tropical forest and associated biodiversity within the next 50 years [8]. Land use is the main sector in which large greenhouse gas emissions reductions must be achieved. In this scenario, biomass, hydropower, solar, and wind energies contribute to most of the electricity generation from 2030 onward [41]. Previous research suggested that climate change will increase future risks to health and well-being [40]. Madagascar has a policy framework to address those challenges: the Disaster Risk Resilience National Strategy for Disaster Risk Management (2016-2030) and the Intended Nationally Determined Contribution (2015-2030). Moreover, the country is committed to mitigating climate change (Law No. 98-1068 of 18 December 1998, ratifying the United Nations Framework Convention on Climate Change; implementation of the Hyogo Framework for Action in 2005; Sendai 
Framework in 2015; Paris Agreement in 2016), reducing the climate change vulnerability, and promoting effective adaptation measures.

\subsection{Future Changes in Water Stress, Water Demand, and Water Supply}

Climate change is a significant element in the forward projection of water availability. The availability of water is a key factor for the development of agriculture and industry, as well as a requirement in satisfying the increasing needs of populations as standards of living are improved. Limitations of water availability will often form a major constraint on development plans [19]. Consequently, inadequate knowledge of the physical, technical, and socioeconomic aspects of water resources induces degradation of river basins.

The projections presented in Figure 2 indicate that the Maningory (4), Tsiribihina (6), and Mangoky (8) basins will experience water stress (low-to-medium, 10-20\%), most notably in the central-western and eastern regions of Madagascar. The projected changes in the total blue water (water supply) in the Mahajamba (1) and Maningoro (4) basins (located in the northern and eastern regions) are much higher (100-300 cm) compared with changes in the Mangoky (8), Onilahy (9), and Mandrare (11) basins $(10-30 \mathrm{~cm})$. The future water demand will be higher in the Maningory (4), Betsiboka (3), Tsiribihina (6), Mangoro (7), and Mangoky (8) basins (10-30 cm), which are located in the central highlands. Overall, the projections indicate an increasing water demand, water stress, and water supply in the major river basins. Factors that may induce pressure on water resources include socioeconomic growth, urbanization, agricultural expansion, and climate change. This would result in water scarcity for agriculture, drinking, and other domestic purposes in those river basins.

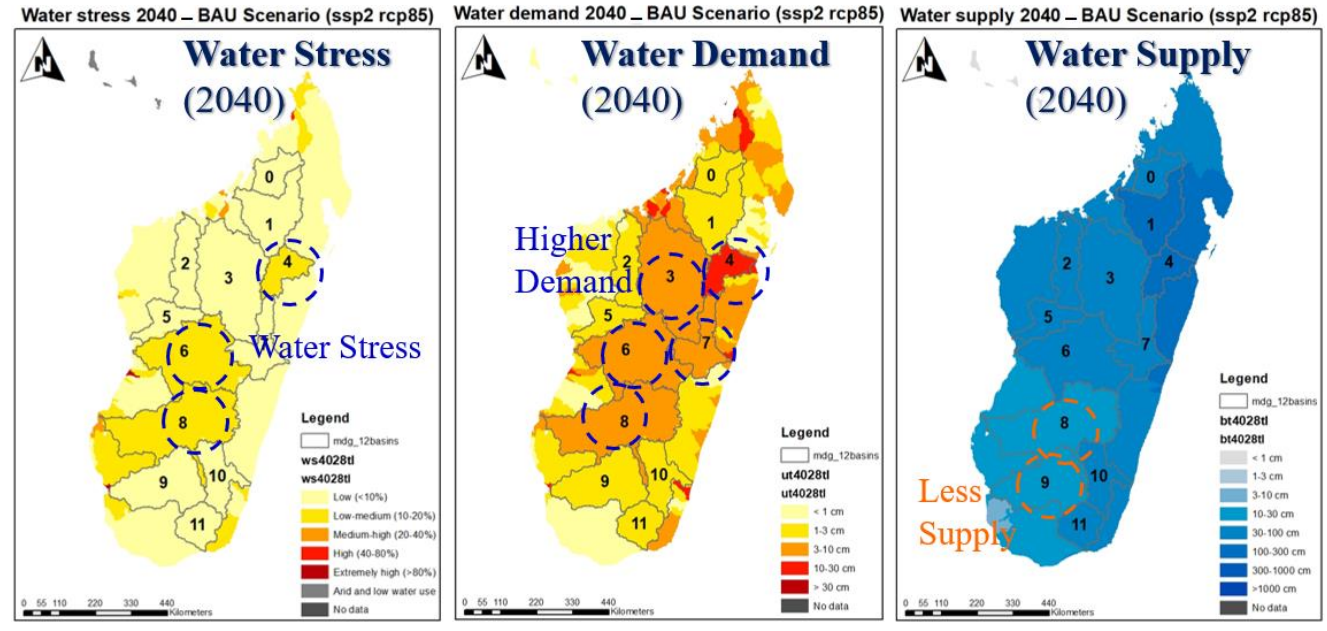

Figure 2. Projected change of water stress, water demand, and water supply from the baseline (1950-2010) to a future period (2040) under the business-as-usual scenario RCP8.5/SSP2. Source: WRI Aqueduct projections 2015 (Data available at https:/ / www.wri.org/aqueduct, accessed on 25 May 2020).

Figure 3 shows that the water stress score is higher in Japan than in Madagascar. As indicated in Table 2, Japan's water stress score is medium-to-high (20-40\%), while it will remain low-to-medium (10-20\%) for Madagascar under the business-as-usual scenarios for the years 2020, 2030, and 2040. Notably, the agricultural sector has the highest water stress score in both countries. Thus, the agricultural sector consumes a larger amount of water, compared with other sectors; there is less competition among users in the industrial sector than in the agricultural sector. Agriculture is the driver of Madagascar's economy. In particular, agriculture dominates the overall use of Madagascar's land and water resources, and it provides livelihoods for more than $70 \%$ of the population [42]. Although Japan is an industrialized country, the agricultural sector is considered a very important sector, which 
dominates $65 \%$ of water use [43]. These results indicate that action must be taken to ensure that there is sufficient water in the future for both humans and the environment.

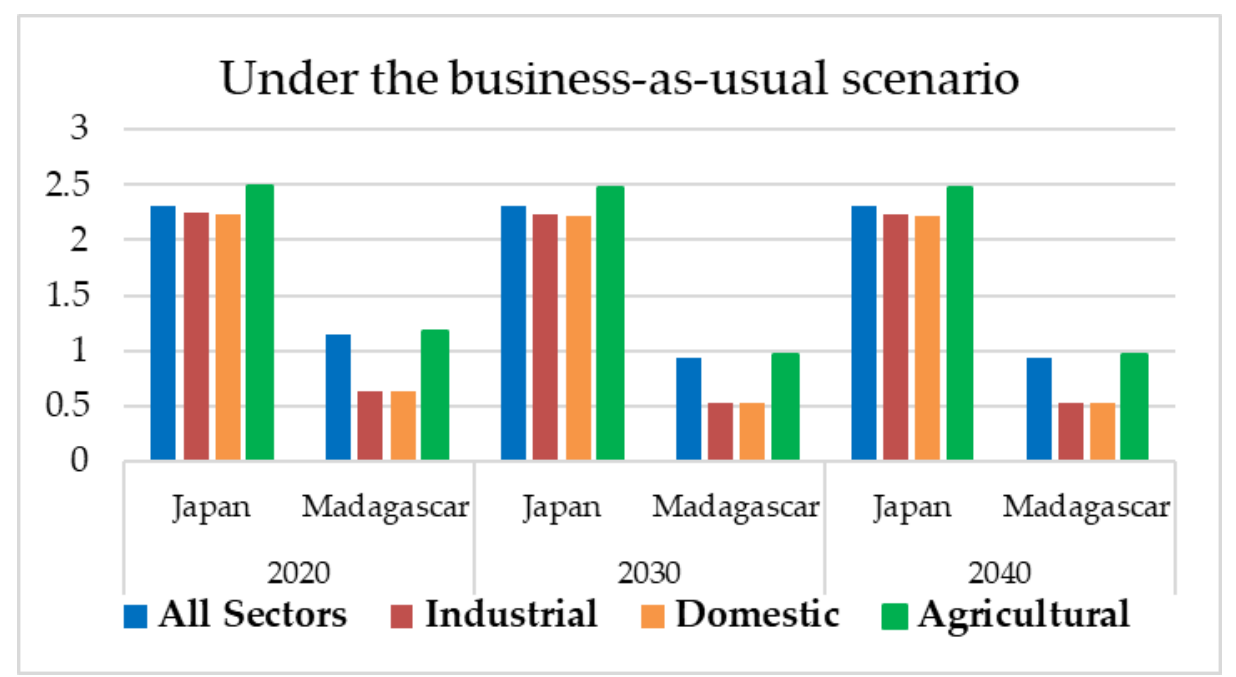

Figure 3. Comparison of water stress in Madagascar and Japan. Source: Aqueduct 3.0 Country and Province Rankings.

Table 2. Water stress score range.

\begin{tabular}{cc}
\hline Score & Value \\
\hline $0-1$ & Low $(<10 \%)$ \\
\hline $1-2$ & Low-to-medium $(10-20 \%)$ \\
\hline $2-3$ & Medium-to-high $(20-40 \%)$ \\
\hline $3-4$ & High $(40-80 \%)$ \\
\hline $4-5$ & Extremely high $(>80 \%)$ \\
\hline
\end{tabular}

\subsection{Problem-Solving Based on Japan's IRBM Experience}

Relevant information about the existing IWRM policy, legal and strategic frameworks and their importance for the SDGs, and climate change in both countries were investigated in the previous sections. The results indicate that Madagascar has several water resources and climate change-related issues. We found that climate change induces pressure on water availability. The projections indicate an increasing water demand, water stress, and water supply in the major river basins. A reasonable approach to tackle those issues could be the adoption of effective and sustainable policies as shown in the case of Japan.

The findings of this study show that Japan has decentralized water policies and effective coordination among the central and local governments [17]. This water plan identifies long-term water supply and demand prospects, as well as means of improving water use stability, through water efficiency measures and effective use of the existing infrastructure [18]. In addition, the country has developed region-specific integrated water resources management tailored to regional climatic and social conditions. The most important relevant finding was the integration of the five ministries related to water to ensure better integration and coordination of the water resources. This intersectoral approach helps to solve the problem of overlapping responsibilities and conflicting decisions.

Regarding the adaptation to climate change through IWRM, the country adopted an integrated approach to managing surface water and groundwater by considering the balance between water supply and water demand, as well as between water quantity and quality. Indeed, stakeholder participation and information sharing help to cope with climate change and social needs. Japan's IWRM promotes sustainable water use and effective water cycle governance through an appropriate policy and frameworks involving relevant sectors 
and stakeholders. IWRM is promoted from perspectives such as groundwater and surface water, water quantity, and water quality (both upstream and downstream); it also promotes water efficiency and environmental conservation. Stakeholder integration in water facility planning, designing, and operation is embedded in the policy framework [15]. Japan's river management system integrates flood management, water utilization, and environmental conservation. The establishment of several laws increases the resilience of water systems to global change pressures (dams, groundwater, waterworks; sewerage, water pollution control, etc.). Concrete action must be implemented to preserve water resources and manage the major river basins. Effective implementation of IWRM now requires all sectors to work together to achieve the shared vision of peaceful economic development. The establishment of the IRBM framework is recommended to enable the major river basins to optimally use their water resources to meet the needs of the people.

On the whole, these findings suggest that successful implementation of the IWRM approach in Madagascar needs systematic planning and implementation to achieve sustainable and resilient solutions Figure 4. In the context of Japan's experience, this proposed framework shows the process from a problem's discovery to the resolution. First, we identified the main issues and the elements that caused those issues in terms of river basin management (Sections 3.2 and 3.3). Then, we considered the structure of the problem by recognizing the connections among the elements and searched for leverage points to improve the situation. Finally, we proposed appropriate solutions to solve the problems by using systematic methodologies. The river basin management in Madagascar has challenges because of political, environmental, social, and water resources issues. Those issues are interconnected and affect water resources in terms of quality and quantity. The proposed framework considers seven important solutions: research and technology prioritization and usage, infrastructure creation, local consultation and participation, sectoral integration, effective governance, information and telecommunications technology and capacity building, and financial resources.

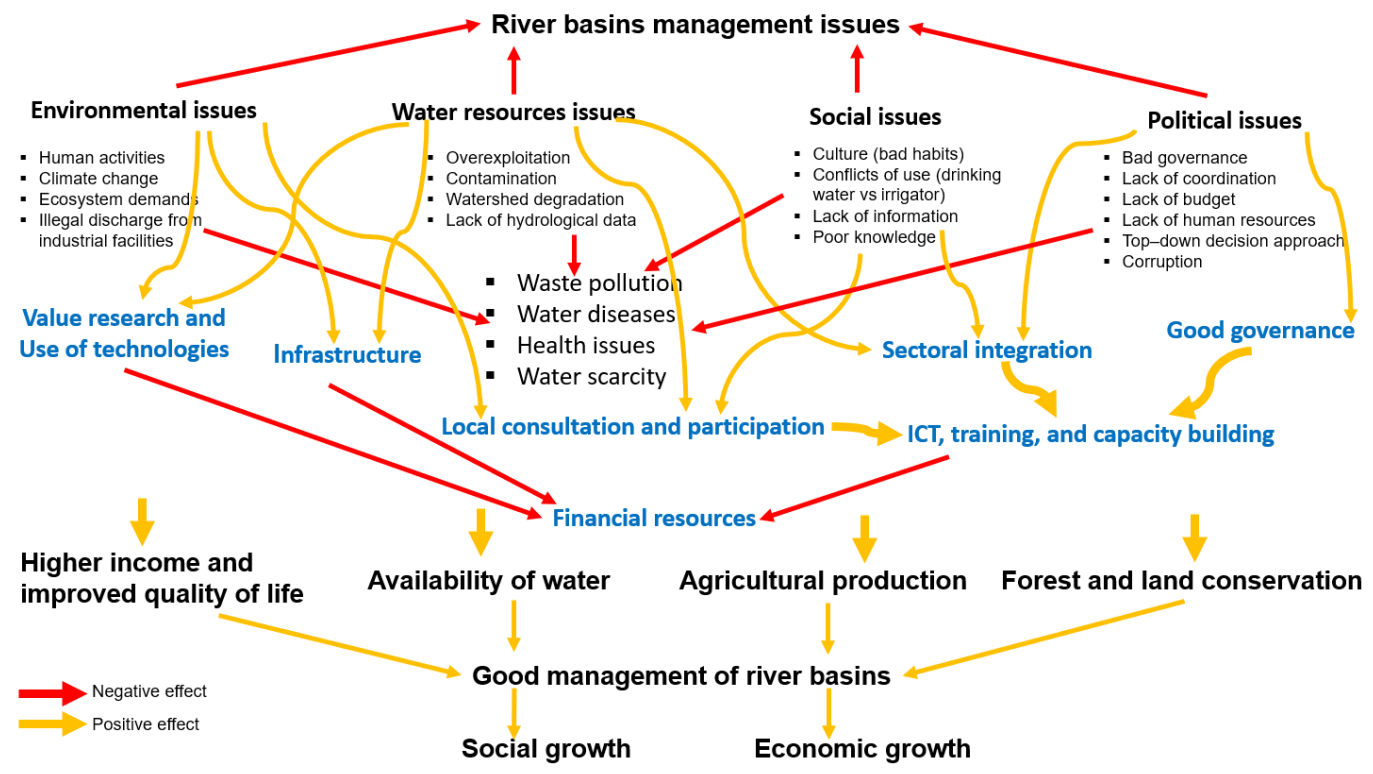

Figure 4. Example of the systemic thinking approach to IWRM in Madagascar.

\section{Conclusions and Recommendations}

This paper investigated the current condition of IWRM in Madagascar, evaluated its sustainability, and compared it with the one in Japan. Relevant information about the existing IWRM policy, legal and strategic frameworks, Sustainable Development Goals (SDGs), and climate change in both countries were investigated. The effects of climate change were analyzed using Aqueduct data under SSP2 RCP85 scenarios. This study revealed two important findings. First, Madagascar and Japan differ greatly in terms of 
IWRM implementation for river basin management. Second, climate change will decrease the available water resources in Madagascar by 2040. Based on the lessons learned from river basin management in Japan, our findings suggest reinforcement of water management for the major river basins through flexible and adaptive policies, systemic thinking and planning, and capacity-building programs. We recommend the establishment of the intersectoral approach that integrates all the ministries related to water to ensure better coordination of the water resources as shown in the case of Japan. This study suggests a regular revision and update of Madagascar's framework documents in terms of the national and global contexts such as climate change, natural hazards, and population needs. When using Aqueduct data, our analysis found that the Maningory, Tsiribihina, and Mangoky basins (in the west and the east) will experience water stress; the demand will be higher in the Maningory, Betsiboka, Tsiribihina, Mangoro, and Mangoky basins (in the highlands), while less water will be available in the Mangoky, Onilahy, and Mandrare basins (in the south). The evidence from these findings suggests that considerable attention must first be paid to the Maningory, Tsiribihina, and Mangoky basins when implementing IRBM across the 12 river basins.

We conclude that the implementation of IWRM is operational, but requires clearer programming and integrated planning. Japan is internationally recognized for its experience in IWRM, as well as its effective and resilient IRBM institutions. The country has many tools available for IWRM planning, monitoring, evaluation, and budgeting. The establishment of an integrated river management system for flood management, water utilization, and environmental conservation was helpful for stakeholders at the ground level. Japan's law requires public participation during the planning, which makes river basin management very specific. There is a need for a better understanding of the positioning and relationships between stakeholders to ensure that they are effectively and efficiently involved in the process. It was shown that Madagascar established an IWRM legal framework aligned with the Sustainable Development Goals; however, their application remains limited and should be re-examined. The results of this study indicate that the unsuccessful implementation of various structures (basin agencies and basin committees), non-application of framework documents, lack of coordination and budget have made the current river management strategies unsustainable. The ground realities for water management in Madagascar indicate that concepts of IWRM or IRBM are not just a myth. Many projects started IWRM implementation at the catchment and small basin levels. Effective frameworks and policies are responsible for the implementation of IRBM at the major river basins. The Malagasy government must implement concrete actions to manage and preserve water resources more effectively. The proposed framework and Japan's experience in river basin management can contribute to solving the current and future water scarcity. The findings of this study will serve to enhance the knowledge concerning the link between IWRM implementation and the impacts of climate change in Madagascar; they may assist in actions taken by the Malagasy government. A great effort is needed to address the current and future challenges for river basin management, to achieve SDG 6.5. The present study makes several noteworthy contributions to the WASH sector in Madagascar. The findings should be considered for the update of the current Water Code which is currently in process.

There are several issues related to water resources and river basin management. The current study only examined the issues of water availability and demand across the major river basins in Madagascar. It is important to note that the comparison with Japan was the first step of the study because, as highlighted in this paper, these countries have similar characteristics. Future studies on the current topic should be conducted to investigate other issues related to river basin management and comparison with other countries are therefore recommended for implementation of the most appropriate IRBM/IWRM approaches in Madagascar. 
Author Contributions: Conceptualization, by R.Z.H.; methodology, R.Z.H. and I.H.; writingoriginal draft preparation, R.Z.H.; writing—review and editing R.Z.H. and I.H.; supervision, I.H.; All authors have read and agreed to the published version of the manuscript.

Funding: This research received no external funding.

Institutional Review Board Statement: Not applicable.

Informed Consent Statement: Not applicable.

Data Availability Statement: Data supporting the reported results can be found in WRI Aqueduct projections 2015 (Data available at https: / www.wri.org/aqueduct, accessed on 25 May 2020).

Acknowledgments: The authors would like to acknowledge the Interdisciplinary Center for River Basin Environment (ICRE), University of Yamanashi, Japan International Cooperation Agency (JICA), ABE Initiative Program for supporting this study.

Conflicts of Interest: The authors declare no conflict of interest.

\section{References}

1. Crestaz, E.; Cimmarrusti, Y.; Farinosi, F.; Biedler, M.; Amani, A.; Mishra, A. Implementing the Water-Energy-Food-Ecosystems Nexus and Achieving the Sustainable Development Goals Implementing the Water-Energy-Food-Ecosystems Nexus and Achieving the Sustainable Development Goals; UNESCO, European Union and IWA: Paris, France; EU: Fermi, Italy; IWA: London, UK, 2021.

2. WWAP/UN-Water. The United Nations World Water Development Report 2018: Nature-Based Solutions for Water; UNESCO: Paris, France, 2018.

3. United Nations Department of Economic and Social Affairs (UNDESA). World Population Prospects: Key Findings and Ad-vance Tables-The 2017 Revision; UNDESA: New York, YN, USA, 2017.

4. Wada, Y.; Flörke, M.; Hanasaki, N.; Eisner, S.; Fischer, G.; Tramberend, S.; Satoh, Y.; van Vliet, M.T.H.; Yillia, P.; Ringler, C.; et al. Modeling global water use for the 21st century: The Water Futures and Solutions (WFaS) initiative and its approaches. Geosci. Model Dev. 2016, 9, 175-222. [CrossRef]

5. Infrastructure Department and Department of Social Development. Madagascar: Rural Drinking Water Supply and Sanita-tion Programme Appraisal Report. Available online: https://www.afdb.org/fileadmin/uploads/afdb/Documents/Project-andOperations /MG-2005-138-EN-ADF-BD-WP-MADAGASCAR-RURAL-WATER-SUPPLY-AND-SANITATION-PROGRAMME. PDF (accessed on 5 November 2021).

6. Rasolofomanana, L.H. Vitality E Vulnerability; WaterAid Madagascar: Antanananarivo, Madagascar, 2016.

7. Conseil, L.E.; Redressement, T.D.E. Portant Code de L' Eau; Journal Officiel de la République Malagasy (J.O. ${ }^{\circ} 2557$ E.S.): Tananarive, Madagascar, 1999.

8. Vieilledent, G.; Grinand, C.; Rakotomalala, F.A.; Ranaivosoa, R.; Rakotoarijaona, J.-R.; Allnutt, T.F.; Achard, F. Combining global tree cover loss data with historical national forest cover maps to look at six decades of deforestation and forest fragmentation in Madagascar. Biol. Conserv. 2018, 222, 189-197. [CrossRef]

9. Eckstein, D.; Künzel, V.; Schäfer, L.; Winges, M. Global Climate Rate Index 2020; Germanwatch e.V: Berlin, Germany, 2020.

10. Elimelech, M. The global challenge for adequate and safe water. J. Water Supply Res. Technol. AQUA 2006, 55, 3-10. [CrossRef]

11. Akers, D.B.; Buerck, A.; MacCarthy, M.F.; Cunningham, J.A.; Mihelcic, J.R. Estimates of Blood Lead Levels (BLLs) for Chil-dren in Coastal Madagascar: Accounting for Dietary Uptake of Lead (Pb). Expo. Health 2019, 12, 501-511. [CrossRef]

12. USAID. Country Development Cooperation Strategy (CDCS); USAID/Madagascar: Antanananarivo, Madagascar, 2020.

13. Paulo. 2021_USAID_CDC Annex-Madagascar.pdf. ペインクリニック学会治療指針 2, 2019. pp. 1-9. Available online: https: //www.climatelinks.org/sites/default/files/asset/document/2021-03/2021_USAID_CDCAnnex-Madagascar.pdf. (accessed on 5 November 2021).

14. GWP IWRM. Survey and Status Report: Madagascar. Glob. Water Partnersh. 2009, 3, 1-29. Available online: https://www.gwp. org/globalassets/global/gwp-saf-files/madagascar-iwrm-report.pdf (accessed on 8 March 2020).

15. Godou, H. River Basin Management in Japan -Flood Control Measures, Water Resources Management. Semin. Integr. Water Resour. Manag. 2008, 5, 1-31. Available online: http://www.mlit.go.jp/river/basic_info/english/pdf/conf_04-0.pdf (accessed on 29 June 2020).

16. Kamarudin, H.; Abdullah, N.; Mizunoya, T.; Yuzir, A.; Yabar, H. Integrated Water Resources Management Implementation for Langat and Sagami River Basins: A Comparison. Jpn. Sect. Reg. Sci. Assoc. Int. 2019, 3, 1-8. Available online: https: //www.ses-tsukuba.jp/wysiwyg/file/download/1/570 (accessed on 10 January 2021).

17. Sim, L.M.; Onishi, A.; Gervais, O.; Chan, N.W. Comparative Research on River Basin Management in the Sagami River Basin (Japan) and the Muda River Basin (Malaysia). Resources 2018, 7, 33. [CrossRef]

18. Japan Water Resources Department. Achieving Water Security in Japan and Worldwide. 2003, p. 4. Available online: https:/ / www.mlit.go.jp/tochimizushigen/mizsei/water_resources/contents/Achieving\%20Water\%20Security \%20in \%20 Japan\%20and\%20Worldwide.pdf (accessed on 7 February 2021). 
19. World Meteorological Organization. Technical Material for Water Resources Assessment; WMO: Geneva, Switzerland, 2012. Available online: http://www.wmo.int/pages/prog/hwrp/publications/Technical_report_series/1095_en_4_Web.pdf (accessed on 25 May 2020).

20. Luck, M.; Landis, M.; Gassert, F. Aqueduct Water Stress Projections: Decadal projections of water supply and demand using CMIP5 GCMs. Technical Note. World Resour. Inst. 2015, 3, 1-20. Available online: Wri.org/publication/aqueduct-water-stress-projections (accessed on 25 May 2020).

21. WRI. Aqueduct Water Risk Atlas, Aqueduct. 2019. Available online: https://wri.org/applications/aqueduct/water-risk-atlas (accessed on 25 May 2020).

22. United Nations United Nations. Conference on Sustainable Development, Rio+20. Sustain. Dev. Knowl. Platf. 2013, 10, 1-37. Available online: https: / / sustainabledevelopment.un.org/rio20 (accessed on 25 May 2020).

23. Politique, F.; Niveau, D.E.H. Forum Politique de Haut Niveau Rapport National de Revue Du Processus de L Agenda 2030 Pour le Developpement Durable. 2016. Available online: https://sustainabledevelopment.un.org/content/documents/1072 3Madagascar_Final\%20Version.pdf (accessed on 15 July 2021).

24. Twinoburyo, E.N.; Henao, L.; Dushime, O.; Simkoko, A.; Kassa, Y.; Ndahiro, D. Africa 2030 SDGs three year reality check report. Sustain. Dev. Goals Cent. Afr. 2019, 5, 1-136.

25. MOFA. Japan's Efforts for Promoting the SDGs; Ministry of Foreign Affairs of Japan: Tokyo, Japan, 2019; pp. 1-5.

26. Shah, B.T. Increasing water security: The key to implementing the Sustainable Development Goals. Glob. Water Partnersh. (GWP) TEC Backgr. Pap. 2016, 22, 52.

27. WHO and UNICEF. Progress on Household Drinking Water, Sanitation and Hygiene 2000-2017. Special Focus on Inequalities; United Nations Children's Fund (UNICEF) and World Health Organization: New York, NY, USA, 2019; pp. 1-71.

28. Rasolofomanana, L.H. Review of the Implementation of Water Code in Madagascar, 2019th ed.; WaterAid Madagascar: Antanananarivo, Madagascar, 2019.

29. House, P.C.; Representative, W.C. WaterAid Madagascar, Growth (Lakeland); WaterAid Madagascar: Antanananarivo, Madagascar, 2016; pp. 1-36.

30. R. pSEau-ONG CITE. Compte-Rendu Rencontre d 'Échanges et Visites Sur Terrain Gestion Intégrée des Ressources en Eau: Qu' Est-Ce Que La GIRE et Comment Est-Elle Mise en Guvre à Madagascar? 2018. Available online: https://www.pseau.org/ outils/ouvrages/cite_ps_eau_compte_rendu_de_la_rencontre_d_echanges_sur_la_gire_a_fianarantsoa_2018.pdf (accessed on 27 March 2021).

31. Omachi, T. The River Law with commentary by article, legal framework for river and water management in Japan. Infrastruct 1999, 4, 1-248.

32. Ministry of Construction, Japan, River Bureau. THE RIVER LAW; Ministry of Construction, Japan, River Bureau: Tokyo, Japan, 1999; p. 76.

33. Ran'Eau. Regional Sector Review 2020 Vakinankaratra Water, Sanitation, Hygiene Sector and Exchange Meeting and Field VisitIntegrated Water Resources Management in Madagascar, 2020. Available online: https://www.pseau.org/outils/ouvrages/ran_ eau_compte_rendu_reunion_d_echanges_gire_antsirabe_2021.pdf (accessed on 15 August 2021).

34. Nachmany, M.; Fankhauser, S.; Davidová, J. The 2015 Global Climate Legislation Study Summary for Policy Makers. 2015 Available online: http://www.lse.ac.uk/GranthamInstitute/wp-content/uploads/2015/05/Global_climate_legislation_study_ 20151.pdf (accessed on 6 March 2021).

35. United Nations Framework Convention on Climate Change. Madagascar's Intended Nationally Determined Contribution; Primature de Madagascar: Antananarivo, Madagascar, 2015; pp. 1-13. Available online: https://www4.unfccc.int/sites/ndcstaging/ PublishedDocuments/Madagascar\%20First/Madagascar\%20INDC\%20Eng.pdf (accessed on 27 April 2020).

36. Nematchoua, M.K.; Ricciardi, P.; Orosa, J.A.; Buratti, C. A detailed study of climate change and some vulnerabilities in Indian Ocean: A case of Madagascar island. Sustain. Cities Soc. 2018, 41, 886-898. [CrossRef]

37. Seidl, R.; Thom, D.; Kautz, M.; Martin-Benito, D.; Peltoniemi, M.; Vacchiano, G.; Wild, J.; Ascoli, D.; Petr, M.; Honkaniemi, J.; et al Forest disturbances under climate change. Nat. Clim. Chang. 2017, 7, 395-402. [CrossRef] [PubMed]

38. Hannah, L.; Dave, R.; Lowry, P.P.; Andelman, S.; Andrianarisata, M.; Andriamaro, L.; Cameron, A.; Hijmans, R.; Kremen, C.; MacKinnon, J.; et al. Climate change adaptation for conservation in Madagascar. Biol. Lett. 2008, 4, 590-594. [CrossRef] [PubMed]

39. World Health Organization; United Nations Framework Convention on Climate Change. Climate and Health Country Profile-2015 Madagascar Demographic Estimates; World Health Organization: Geneva, Switzerland, 2015. Available online: http://www.wri.org (accessed on 4 June 2021).

40. Rakotoarison, N.; Raholijao, N.; Razafindramavo, L.M.; Rakotomavo, Z.A.P.H.; Rakotoarisoa, A.; Guillemot, J.S.; Randri-amialisoa, Z.J.; Mafilaza, V.; Ramiandrisoa, V.A.M.P.; Rajaonarivony, R.; et al. Assessment of Risk, Vulnerability and Adap-tation to Climate Change by the Health Sector in Madagascar. Int. J. Environ. Res. Public Health 2018, 15, 2643. [CrossRef] [PubMed]

41. Nogueira, L.P.; Longa, F.D.; van der Zwaan, B. A cross-sectoral integrated assessment of alternatives for climate mitigation in Madagascar. Clim. Policy 2020, 20, 1257-1273. [CrossRef]

42. FAO. Country Fact sheet-Madagascar; Food and Agriculture Organization of the United Nations: Antanananarivo, Madagascar, 2016. Available online: https://storage.googleapis.com/fao-aquastat.appspot.com/countries_regions/factsheets/summary_ statistics/en/MDG-CF.pdf (accessed on 10 July 2021).

43. Roy, K. Water Resources in Relation to Major Agro-Environmental Issues in Japan. J. Dev. Sustain. Agric. 2007, 2, 27-34. [CrossRef] 